\title{
DEMOKRASI DAN BUDAYA POLITIK INDONESIA
}

Dedimus Kodi

IIK STRADA INDONESIA

Dedimuskodi5@gmail.com

\begin{abstract}
ABSTRAK
Demokrasi adalah bentuk atau mekanisme sistem pemerintahan suatu Negara sebagai upaya untuk mewujudkan kedaulatan rakyat (kekuasaan warga Negara) atas negara untuk di jalankan oleh pemerintahan Negara tersebut.

Budaya politik sangat berpengaruh untuk melihat tingkat kehidupan demokratis suatu Negara. Budaya politik merupakan variabel determinan atau berpengaruh terhadap sistem politik. Demokratisasi tidak berjalan baik apabila tidak di tunjang oleh terbangunnya budaya politik yang sesuai dengan prinsip-prinsip demokrasi. Indonesia adalah sebuah wilayah dengan karasteristik budaya masyarakat yang unik dan kompleks. Dilihat dari segi asal-usulnya, masyarakat indonesia merupakan produk sejarah dari campuran berbagai macam ras, yang membangun kehidupan bersama dan bersebaran, dari banyak pulau/kepulauan, dengan identitas religus yang di pengaruhi oleh terutama empat corak agama besar (Hindu, Budha, Islam, dan Kristen), dan terdiri dari ratusan jumlah etnik dengan bahasa yang berlainan, dan sebagainya. Demokrasi tidak hanya merupakan bentuk pemerintahan, tetapi tetapi menjadi sistem politik.
\end{abstract}

Semua yang di tulis ini berdasarkan referensi jurnal untuk di kembangkan lagi oleh penulis. Tujuan dari penulisan ini adalah mengetahui demokrasi dan budaya politik indonesia serta hubungan politik dengan demokrasi 


\section{LATAR BELAKANG}

Hasil penelitian menyatakan "mungkin untuk pertama kali dalam sejarah, demokrasi di nyatakan sebagai nama yang paling yang paling baik dan wajar untuk semua sistem organisasi politik dan sosial yang di perjuangkan oleh para pendukungnya yang berpengaruh" (UNISCO 1949). Hampir semua Negara telah di dunia meyakini demokrasi sebagai "tolak ukur tak terbantah dari keabsahan politik". Keyakinan bahwa kehendak rakyat adalah dasar utama kewenangan pemerintah menjadi basis bagi tegak kokohnya sistem politik demokrasi. Hal itu menunjukkan bahwa rakyat di letakkan pada posisi penting walaupun secara operasional implikasinya di berbagai Negara idak terlalu sama. Tidak ada Negara yang ingin di katakana sebagai Negara yang tidak berdemokratis atau Negara otoriter.

Demokrasi merupakan salah satu
bentuk atau mekanisme sistem
pemerintahan suatu Negara sebagai upaya
mewujudkan kedaulatan rakyat atau Negara
yang di jalankan oleh pemerintah. Semua
warga Negara memiliki hak yang setara
dalam pengambilan keputusan yang dapat
mengubah hidup mereka. Demokrasi
mengijinkan warga Negara untuk
berpartisipasi baik secara langsung atau
melalui perwakilan dalam perumusan,
pengembangan dan pebuatan hukum.

Budaya politik nerupakan sistem nilai dan keyakinan yang di miliki bersama oleh masyarakat. Namun, setiap unsur masyarakat berbeda pula politiknya, seperti antara masyarakat umum dengan para elitenya. Seperti juga di indonesia, menurut Benedict R. OG Anderson, kebudayaan indonesia cenderung membagi secara tajam antara kelompok elit dengan kelompok massa.
Negara indonesia sebagai Negara demokratis membutuhkan warga Negara yang berbudaya politik partisipan dan berorientasi setia atau mendukung sistem politik nasional. Warga Negara yang berciri demikian inilah yang memang di butuhkan bagi sistem politik demokrasi di indonesia.

Kehidupan manusia di dalam masyarakat memiliki peran penting dalam sistem politik dalam suatu Negara. Manusia dalam kedudukannya sebagai makhluk sosial, senantiasa akan berinteraksi dengan manusia lain dalam upaya mewujudkan kebutuhan hidupnya. Kebutuhan hidup manusia tidak cukup yang bersifat dasar, seperti makan, minum, biologis, pakaian dan papan(Rumah). Lebih dari itu juga mencakup kebutuhan akan pengakuan eksistensi diri dan penghargaan dari orang lain dalam bentuk pujian, pemberian upah kerja, status sebagai anggota masyarakat, anggota bagi suatu partai politik tertentu dan sebagainya.

Demokrasi mencakup kondisi sosial, ekonomi, dan budaya yang memungkinkan adanya praktik kebebasan politik secara bebas dan setara. Demokrasi indonesia di pandang perlu dan sesuai dengan pribadi bangsa indonesia. Hal itu bisa kita temukan dari banyaknya agama yang masuk dan berkembang di indonesia, selain itu banyaknya suku, budaya dan bahasa, semuanya merupakan karunia Tuhan yang patut kita syukuri

\section{KASUS MASALAH}

1. Apa pengertian demokrasi demokrasi?

2. Apa saja jenis-jenis Dermokrasi?

3. Bagaiman budaya politik dan demokratif. 


\section{TUJUAN}

1. Memenuhi tugas kuliah

2. Memahami arti demokrasi

3. Mengenal jenis-jenis demokrasi

4. Untuk memahami budaya politik dan demokratif

\section{PEMBAHASAN}

\subsection{Pengertian Demokrasi}

Demokrasi adalah bentuk pemerintahan dimana semua warga negaranya memiliki hak yang sama pengambilan keputusan yang dapat menubah hidup mereka. Demokrasi mengijinkan warga Negara indonesia berpartisipasi baik secara langsung atau melalui perwakilan dalam perumusan, pengembangan, dan pembuatan hukum. Demokrasi mencakup kondisi sosial, ekonomi, dan budaya yang memungkinkan adanya praktik kebebasan politik secara bebas dan setara. Demokrasi juga mrupakan seperangkat gagasan dan prinsip tentang keebasan beserta praktik dan prosedurnya. Demokrasi mengandung makna penghaegaan terhadap harkat dan martabat manusia.

Demokrasi sebagai suatu sistem telah di jadikan alternatif dalam berbagai tatanan aktivitas bermasyarakat dan bernegara di beberapa Negara. Seperti di akui oleh Moh, Mahfud Md, ada dua alasan di pilihnya demokrasi sebagai sistem bermasyarakat dan bernegara. Pertama, hampir semua Negara di dunia ini telah menjadikan demokrasi sebagai asas yang fundamamental.; Kedua, demokrasi sebagai asas kenegaraan secara esensial telah memberikan arah bagi peranan masyarakat untuk menyelenggarakan Negara sebagai organisasi tertingginya. Oleh karena itu, di perlukan pengetahuan dan pemahan yang benar pada warga masyarakat tentang demokrasi.

Pengertian demokrasi dapat di lihat dari tinjaun bahasa (epistemologis) dan istila (terminologis). Secara epistemologis “ dekrasi" terdiri dari dua kata yang berasal dari bahasa yunani yaitu "demos" yang berarti rakyat atau penduduk suatu tempat dan "cretei" atau " cratos" yang berarti kekuasaan atau kedaulatan. Jadi secara bahasa demos-cratein atau demos- cratos adalah keadaan negera di mana dalam sistem pemerintahan nya kedaulatan berada di tangan rakyat, kekuasaan tertinggi berada dalam keputusan bersama rakyat, rakyat berkuasa, pemerintah rakyat dan oleh rakyat.

Sebagai sebuah konsep, demokrasi memiliki makna luas dan mengandung banyak elemen yang kompleks. Demokrasi adalah suatu metode politik, sebuah mekanisme untuk memilih pemimpin politik. Warga Negara di beri kesempatan untuk memilih salah satu di antara pemimpin-pemimpin politik yang bersaing meraih suara (Dafid lechmn, 1989). Kemampuan untuk memilih di antara pemimpin-pemimpin politik pada masa pemilihan inilah yang di sebut demokrasi. Jadi dengan kata lain dapat di ungkat bahwa demokrasi adalah suatu metode penataan kelembagaan untuk sampai pada keputusan politik, dimana individu meraih kekuasaan untuk mengambil keputusan melalului perjuangan kompotitif dalam meraih suara. Namun demikian, proses kompetisi itu harus tetap di bingkai oleh etika normatif yang mengarah pada terjadinya equilibrium sosial. 


\subsection{Jenis-Jenis Demokrasi}

Demokrasi memiliki banyak jenisnya. Berikut beberapa jenis dari demokrasi

1. Demokrasi menurut cara aspirasi rakyat

a. Demokrasi langsung

Merupakan sistem demokrasi yang memberikan kesempatan

kepada seluruh warga negaranya dalam

permusyawaratan saat menentukan arah kebijakan umum dari Negara atau undang-undang.

b. Demokrasi tidak langsung Merupakan sistem demokrasi yang di jalankan menggunakan sistem perwakilan.

2. Demokrasi tidak langsung

a. Demokrasi Liberal

Kebebasan individu yang lebih di tekankan dan mengabaikan kepentingan umum.

b. Demokrasi Rakyat

Merupakan demokrasi yang didasarkan pada paham sosialisme dan komunisme dan lebih mengutamakan kepentingan umum atau Negara.

c. Demokrasi Pancasila

Merupakan demokrasi yang ada di indonesia bersumberkan pada nilai-nilai sosial budaya bangsa serta berazaskan musyawarah mufakat dengan memprioritaskan kepentingan seluruh masyarakat atau warga Negara. Demokrasi pancasila fokus pada kepentingan dan asoirasi serta hati nurani rakyat. Sampai saat ini indonesia menganut demokrasi pancasila yang bersumber pada falsafah pancasila

\subsection{Pengertian Budaya Politik}

Konsep budaya politik muncul dan mewarnai wacana ilmu politik pada akhir Perang Dunia II, sebagai dampak perkembangan ilmu politik di Amerika Serikat. Sebagaimana diungkapkan oleh banyak kalangan ilmuwan politik, setelah PD II selesai, di Amerika Serikat terjadi apa yang disebut revolusi dalam ilmu politik, yang dikenal sebagai Behavioral Revolution, atau ada juga yang menamakannya dengan Behavioralism. Behavioral revolution yang terjadi dalam ilmu politik adalah sebagai dampak dari semakin menguatnya tradisi atau madzhab positivisme, sebuah paham yang percaya bahwa ilmu sosial mampu memberikan penjelasan akan gejala sosial termasuk ilmu politik, seperti halnya ilmu-ilmu alam mampu memberikan penjelasan tehadap gejala-gejala alam. Paham ini sangat kuat diyakini oleh tokoh-tokoh besar sosiologi, seperti Herbert Spencer, Auguste Comte, juga Emile Durkheim (Afan Gaffar, 2006: 97) .

Paham positivisme merupakan pendapat yang sangat kuat di Amerika Serikat semenjak Charles E. Merriam mempeloporinya diUniversitas Chicago, yang kemudian dikenal sebagai The Chicago School atau Madzhab Chicago, yang memulai pendekatan baru dalam ilmu politik (Somit and Tannenhaus, 1967; Almond and Verba, 1963; Almond, 1990 dalam Afan Gaffar, 2006: 97). Salah satu dampak yang sangat mencolok dari behavioral revolutuion ini adalah munculnya sejumlah teori, baik yang bersifat grand maupun pada tingkat menengah (middle level theory). Kemudian, ilmu politik diperkaya dengan 
sejumlah istilah, seperti misalnya sistem analysis, interest aggregation, interest articulation, political socialization, politic culture, conversion, rule making, rule dan aplication (Afan Gaffar, 2006: 98). Budaya politik merupakan pola perilaku individu dan orientasinya dalam kehidupan bernegara, penyelenggaraan administrasi negara, politik pemerintahan, hukum, adat istiadat, dan norma kebiasaan yang dihayati oleh seluruh anggota masyarakat setiap harinya (Rusadi Kantaprawira, 2006: 25). Budaya politik juga dapat diartikan sebagai suatu sistem nilai bersama suatu masyarakat yang memiliki kesadaran untuk berpartisipasi dalam pengambilan keputusan kolektif dan penentuan kebijakan publik untuk masyarakat seluruhnya.

Teori tentang sistem politik yang diajukan oleh David Easton, yang kemudian dikembangkan pula oleh Gabriel Almond, hal ini mewarnai kajian ilmu politik pada kala itu (1950-1970). Dan diantara kalangan teoritisi dalam ilmu politik yang sangat berperan dalam mengembangkan teori kebudayaan politik adalah Gabriel Almond dan Sidney Verba, ketika keduanya melakukan kajian di lima negara yang kemudian melahirkan buku yang sangat berpengaruh pada 1960-an dan 1970-an, yaitu The Civic Culture. Civic Culture inilah yang menurut Almond dan Verba merupakan basis bagi budaya politik yang membentuk demokrasi (Afan Gaffar, 2006: 99). Almond (1965:20), menunjukkan bahwa "tiap sistem politik mewujudkan dirinya didalam pola orientasi-orientasi dan tindakan-tindakan politik tertentu". Dalam pengertian yang hampir sama, Lucian W. Pye (1965:24) mendefinisikan budaya politik sebagai "the ordered subjective realism of politic, yaitu tertib dunia subjektif politik". Definisi budaya politik menurut Verba (1965:31) merupakan yang paling jelas. Bahwa "budaya politik", demikian katanya, "menunjuk pada sistem kepercayaankepercayaan tentang pola-pola interaksi politik dan institusi-institusi politik (dalam A. Rahman H.I, 2007: 268). Almond dan Verba menunjuk bukan pada apa yang diyakini orang tentang kejadian-kejadian tersebut dan kepercayaan-kepercayaan yang dimaksud dapat mengenai beraneka jenis, berupa kepercayaan-kepercayaan empirik mengenai situasi kehidupan politik, dapat berupa keyakinan-keyakinan mengenai tujuan-tujuan atau nilai-nilai yang harus dihayati di dalam kehidupan politik dan semuanya itudapat memiliki perwujudan atau dimensi emosional yang sangat penting. Almond dan Verba (1984: 14) mendefinisikan budaya politik sebagai: "Suatu sikap orientasi yang khas warga negara terhadap sistem politik dan aneka ragam bagiannya, dan sikap terhadap peranan warga negara yang ada di dalam sistem tersebut". Miriam Budiardjo menyatakan bahwa salah satu aspek penting dalam sistem politik adalah budaya politik yang mencerminkan faktor subjektif. Budaya politik adalah keseluruhan dari pandangan-pandangan politik, seperti norma-norma, pola-pola orientasi terhadap politik, dan pandangan hidup pada umumnya. Budaya politik mengutamakan dimensi psikologis dari suatu sistem politik, yaitu sikap-sikap, sistem-sistem kepercayaan, simbol-simbol yang dimiliki oleh individu-individu, dan beroperasi di dalam seluruh masyarakat, serta harapan-harapannya (Miriam Budiardjo, 2008: 58-59). Kegiatan politik warga negara, tidak hanya ditentukan oleh tujuan-tujuan yang didambakannya, akan tetapi juga oleh harapan-harapan politik yang dimilikinya dan oleh pandangannya mengenai situasi politik. Bentuk dari budaya politik dalam suatu masyarakat dipengaruhi antara lain oleh sejarah perkembangan dari sistem, oleh agama 
yang terdapat dalam masyarakat itu, kesukuan, status sosial, konsep mengenai kekuasaan dan kepemimpinan. Dengan kata lain, budaya politik suatu bangsa dapat didefinisikan sebagai pola distribusi orientasi-orientasi yang dimiliki oleh anggota masyarakat terhadap objek-objek politik atau bagaimana distribusi pola-pola orientasi khusus menuju tujuan politik diantara masyarakat itu. Lebih jauh dinyatakan, bahwa warga negara senantiasa mengidentifikasikan diri mereka dengan simbol-simbol dan lembaga kenegaraan berdasarkan orientasi yang mereka miliki. Dengan orientasi itu pula mereka menilai serta mempertanyakan tempat dan peranan mereka di dalam sistem politik. Menurut Rusadi Kantaprawira (2006: 25), budaya politik tidak lain adalah pola tingkah laku individu dan orientasinya terhadap kehidupan politik yang dihayati oleh para anggota suatu sistem politik. Pengertian budaya politik diatas, nampaknya membawa kita pada suatu pemahaman konsep yang memadukan dua tingkat orientasi politik, yaitu sistem dan individu. Konsep orientasi mengikuti pengertian Talcott Parsons dan Verba yang mendefinisikan orientasi sebagai aspekaspek dari objek dan hubungan-hubungan yang diinternalisasikan di dalam dunia subjektif individu. Dengan orientasi yang bersifat individual ini, tidaklah berarti bahwa dalam memandang sistem politiknya, kita menganggap masyarakat akan cenderung bergerak ke arah individualisme. Jauh dari anggapan yang demikian, pandangan ini melihat aspek individu dalam orientasi politik hanya sebagai pengakuan akan adanya fenomena dalam masyarakat tertentu, yang semakin mempertegas bahwa masyarakat secara keseluruhantidak dapat melepaskan diri dari orientasi individual (Alfian dan Nazaruddin Sjamsuddin, 1991: 21) Budaya Politik menjadi penting untuk dipelajari dan dipahami karena ada dua sistem. Pertama, sikap warga negara terhadap orientasi politik yang menentukan pelaksanaan sistem politik. Sikap dan orientasi politik sangat mempengaruhi bermacam-macam tuntutan, hal yang diminta, cara tuntutan itu di utarakan, respon dan dukungan terhadap golonganm elit politik, respons dan dukungan terhadap rezim yang berkuasa. Kedua, dengan mengerti sifat dan hubungan antara kebudayaan politik dan pelaksanaan sistemnya, kita akan lebih dapat menghargai cara-cara yang lebih membawa perubahan sehingga sistem politik lebih demokratis dan stabil (A. Rahman H.I, 2007: 269). Budaya politik selalu inhern pada setiap masyarakat yang terdiri dari sejumlah individu yang hidup dalam sistem politik tradisional, transnasional, maupun modern.

\subsection{Budaya politik dan Demokrasi}

Demokrasi berhubungan erat dengan demokratisasi. Demokratisasi adalah sebuah proses politik yang di jalankan oleh pemerintah oleh pemerintah bersama masyarakat untuk menciptakan kehidupan politik yang demokratis. Dalam konteks itu, berlangsungnya demokratisasi penting untuk d liht dengang mengacu kepada dua hal utama yabg menjadi dasar demokrasi. Pertama, adanya seperangkat ketentuan normative (kriteria nilai-nilai) yang harus terpenuhi di dalam masyarakat. Kedua, adanya suatu struktur politik yang berkembang dalam masyarakat.

Demokratisasi pada hakikatnya merupakan suatu proses perubahan politik (political change) dari keadaan yang di anggap lebih kurang demokratis. Alasan bagi adanya perubahan politik itu sendiri adalah di 
sebabkan oleh ketidakpuasan psikologis yang telah di alami bersama oleh sistem politik. Singkatnya, budaya politik tidak lain daripada orientasi psilogis terhadap obyek sosial, dalam hal ini sistem politik. Positif atau negative sikap seseorang trhadap sistem politik yang berkembang menuju kondisi demokratis, adalah tergantung pada corak orientasoi budaya politik yang di miliki.

\section{KESIMPULAN}

Demokrasi adalah bentuk untuk pemerintahan di mana semua warga negaranya memiliki hak yang sama pengambilan keputusan yang dapat mengubah hidup mereka.

Budaya politik merupakan sistem nilai dan keyakinan yang di miliki bersama oleh masyarakat. Namun setiap unsur masyarakat berbeda pula budaya politiknya, seperti antara masyarakat dengan para elitenya. Perlu di bangun karakter budaya politik, sehingga kegiatan "politik" bukanlah panggung bernmain bagi elite-penguasa, tetapi sebagai sarana pemenuhan kebutuhan dasar warga Negara dalam menciptakan kemaslahatan bersama (public good). Masyarakat dalam struktur Negara modern adalah raja yang harus di layani oleh para pejabat atau penguasa, bukan sebaliknya, pelayan harus melayani segala kebutuhan penguasa seperti dalam hierarki sistem politik kuno.

Negara indonesia sebagai Negara demokratis membutuhkan warga Negara yang berbudaya politik partisipan dan berorientasi setia atau mendukung sistem politik nasional. Warga Negara yang berciri demikian inilah yang memang di butuhkan bagi sistem politik demokrasi di indonesi.

\section{DAFTAR PUSTAKA}

Sodik, M. A., Suprapto, S. I., \& Pangesti, D. (2013). Faktor-Faktor Yang Berhubungan Dengan Pelaksanaan Pelayanan Prima Pegawai Di Rsui Orpeha Tulungagung. STRADA Jurnal IImiah Kesehatan, 2(1), 24-32.

Kodi, D. (2021). Persatuan Dan Kesatuan Negara Indonesia.

Kodi, D. (2021). Hak Untuk Mendapatkan Pelayanan Kesehatan Sebagai Warga Negara Indonesia.

Sodik, M. A. (2018). Merokok \& Bahayanya.

Karina, Z., \& Sodik, M. A. (2018). Pengaruh Dukungan Sosial Terhadap Kesehatan.

Dadu, F. D., \& Sodik, M. A. (2021). Penyaluran Bantuan Dana Jaminan Sosial bagi Masyarakat yang Terdampak Covid-19. 
